\title{
PHYSICOCHEMICAL PROPERTIES OF Pinus massoniana WOOD SUBJECTED TO SILICONE OIL HEAT TREATMENT
}

\author{
Kufre Edet Okon ${ }^{1, \star}$, Ubong Ime Udoakpan ${ }^{2}$
}

\begin{abstract}
In this study, Pinus massoniana wood was heat treated with silicone oil to modify the chemical composition relative to the unmodified wood. Specifically, polysaccharide, lignin, extractives and ash contents were the properties investigated. The wood samples were first of all pre-heated in a micro-wave oven to ease heat transfer within the wood. Silicone oil heat treatment was carried out at 150,180 and $210^{\circ} \mathrm{C}$ for $2,4,8 \mathrm{~h}$. The silicone oil heat treated wood was characterized by Fourier transformed infrared (FTIR), thermogravimetric analysis (TGA), X-ray diffraction (XRD) and contact angle. Results showed that silicone oil heat treatment caused significant decrease in the polysaccharide $(\mathrm{P}<0,0001)$ and ash contents $(\mathrm{P}<0,0001)$ and significant increase in the lignin $(\mathrm{P}<0,0001)$ and extractives contents $(\mathrm{P}<0,0001)$ as the treatment time increased. FTIR results showed that the chemical constituents of the wood were affected by the treatment, while TGA showed that the treated wood resulted in higher thermal stability with increase in the crystallinity index. Silicone oil heat treatment proved to be effective in increasing the contact angle of the wood.
\end{abstract}

Keywords: Chemical properties, contact angle, lignin, polysaccharides, thermal modification, wettability.

\section{INTRODUCTION}

Wood is characterized by a porous network structure composed of cell walls made up of biopolymers which endows wood with high strength-to-weight ratio (Sun and Sun 2002), that enables it to be used as a structural material for construction, tools, furniture making, musical instruments and other applications for thousands of years due to its unique porous structure and aesthetic characteristics (Goldstein 1977). But, the wood structures are easily affected by changes in the environment, particularly at high moisture levels (Fuller et al. 1997) and its wood components are easily degraded by microorganisms. Dimensional instability is one of the major shortcomings of wood compared to synthetic materials derived from non-renewable resources (Alma et al. 1996), the change in the dimension of wood is attributed to changes in relative humidity of its environment, thus limiting its use in some applications. Several researchers have reported the behaviour of wood in relation to wood-water interactions (Engelund et al. 2013, Rautkari et al. 2013). Moisture absorption, hemicelluloses polymers play a significant role since they are hygroscopic, accessible, and contain some sugar residues that may serve as feed for microorganisms to start wood degradation (Adebawo et al. 2016, Rowell 2012, Okon et al. 2018b).

Hydroxyl groups are the most abundant functional groups present in the cell wall of wood in the form of

\footnotetext{
${ }^{1}$ Department of Forestry and Natural Environmental Management, Faculty of Agriculture, University of Uyo, Uyo, Nigeria, kufreokon@ uniuyo.edu.ng

${ }^{2}$ Department of Forestry and Natural Environmental Management, Faculty of Agriculture, University of Uyo, Uyo, Nigeria , ubongudoakpan@gmail.com

"Corresponding author: kufreokon@uniuyo.edu.ng

Received: 24.04.2018 Accepted: 12.07.2019
} 
cellulose, hemicellulose and lignin (Chen et al. 2018) and in general possesses a hygroscopic character, which subsequent to water exposure results in wood with poor dimensional stability (Adebawo et al. 2016). The fluctuations and changes in dimension of wood in service is highly undesirable as it functionally and visually affect the performance of wood, leading to cracks and checks within the wood. Many methods have been used to improve the properties in wood, but thermal wood modification at high temperature without chemicals has proven effective, as it is a different method for the improvement of wood properties (Hill 2007, Kocaefe et al. 2008, Militz 2002, Seborg et al. 1953, Missio et al. 2016).

Several thermal treatment methods have been developed and commercialized, among which are Thermo Wood, Plato Wood, Retification Wood and Oil Heat Treatment (Stamm and Tarkow 1947, Hill 2007), with variety of processes that differ in terms of treatment temperature, treatment atmosphere, and medium of heat transfer (Behr et al. 2018), resulting to alteration in the chemical composition of the wood and the cell wall polymers degradation due to thermal oxidation, dehydration and depolymerization of wood components, followed by the evaporation of volatile extractives (Missio et al. 2015, Kučerová et al. 2016). Hemicelluloses are the most thermally susceptible of all the macromolecule polymer components in the cell wall (Hill 2007), and the most hydrophilic of the polymers (Rautkari et al. 2013, Okon et al. 2018a).

Due to thermal modification durability and dimensional stability are enhanced depending on the wood species and treatment intensity (Militz and Altgen 2014). The presence of acetyl groups in hemicelluloses leads to the formation of acetic acid, thus resulting in acid-catalysed degradation of polysaccharides (Kučerová et al. 2016). Cellulose undergoes great modification in its chemistry, crystallinity and microstructure during heat treatment (Dumanli and Windle 2012), and the amorphous regions are the most labile to thermal degradation compared to the crystalline phase (Kučerová et al. 2016). The thermal stability of the cell wall polymers increases in the order of hemicelluloses, cellulose and lignin, however, with extended heat treatment, a chain scission of the cellulose occurs, which results in the decreased degree of polymerization (DP) of cellulose (Kučerová et al. 2011, Kučerová and Výbohová 2014). The degradation of polysaccharides leads to relative increased of lignin content in wood. Several studies have reported that, the mass changes of lignin were less significantly affected at low temperatures, but at higher temperatures its chemical structure was considerably altered by lignin auto-condensation reactions or formation of cross-linked lignin-carbohydrate (LC) complexes (Inari et al. 2006, Tjeerdsma et al. 1998, Sivonen et al. 2002, Wikberg and Maunu 2004, Bhuiyan and Hirai 2005). Other studies reported that thermal treatment of both juvenile and mature wood of Pinus elliottii var. elliottii at $200{ }^{\circ} \mathrm{C}$ resulted in a significant increase in the extractives and insoluble lignin contents (Severo et al. 2012) and Pinus caribaea var. hondurensis tree heat - treated at $180^{\circ} \mathrm{C}$ caused a decrease in the carbohydrate contents (Brito et al. 2008).

Oil heat treatment is another alternative way in treating wood without use of preservatives and this process is considered to be efficient eco-friendly wood treatment method. Stamm (1964) and Welzbacher and Rapp (2004) compared the properties of palm oil, soy oil and slack wax treated wood for different treatment times and temperatures. They asserted that the three oils have different chemical compositions, with the main differences in the saturation degree in chemical bonds: Soy oil is highly unsaturated and is liquid at ambient temperature, palm oil is high in saturated fatty acids among the vegetable oils, being semi-solid at ambient temperature, while slack wax consists mostly of long straight chain hydrocarbons and mineral oil, with excellent water barrier property and the melting point of about $50-70^{\circ} \mathrm{C}$. Furthermore, linseed oil was used in the treatment of Aspen wood (Bazyar 2012), as natural heating medium, hot linseed oil caused equal and fast heat transfer in wood and improved the properties of the wood. In addition, linseed oil has a suitable smoke and the tendency to polymerize and these are important parameters of oil for heat treatment (Sailer and Rapp 2001). Some vegetable oils can be suitable as heat transfer for thermal modification, since the boiling point of most vegetable oils is higher than $260^{\circ} \mathrm{C}$ (Gunstone 2011) and the use of this oils as heating medium is conducive.

In this present research, silicone oil is used as the heating medium in the silicone oil heat treatment of $P$. massoniana wood. Previous studies reported that silicone oil not only served as the heat transfer medium, but also isolated oxygen from the wood during treatment (Okon et al. 2017). It is inherently biodegradable, without toxic effect on humans health and the environment, and net carbon contribution to the atmosphere. To the knowledge of the authors, there are no published data regarding the chemical properties of silicone oil heat treated P. massoniana wood in literature. Wood heat treatment using silicone oil is important for different wood species because it gives characterization of new material properties and provides information for optimization of wood processing. Thus, the aim of this study is to investigate the changes in the chemical composition of P. massoniana as an alternative heat-treatment approach by means of silicone oil. Fourier transform infra-red (FTIR), thermogravimetric analysis (TGA), X-ray diffractogram (XRD) and wettability on the silicone oil modified wood were evaluated. This study is a preliminary study to understand the wood structure alteration 
after treatment with silicone oil.

\section{MATERIAL AND METHODS}

\section{Specimen preparation}

The wood species used in this study was 25-year-old Chinese pine (Pinus massoniana L.) obtained from Fuzhou, $\left(26^{\circ} 04^{\prime} 34^{\prime \prime} \mathrm{N}, 119^{\circ} 18^{\prime} 23^{\prime \prime} \mathrm{E}\right)$, a fast-growing wood planted across Fujian Province, People's Republic of China. The density of the wood was $431 \mathrm{kgm}^{-3}$ with annual growth of $41 \mathrm{a}$. Silicone oil was purchased from Chemicals Regent Beijing Company Limited, Beijing, P. R. China. Wood samples were cut into test specimens and were thermally modified in a laboratory process. Sapwood from the wood were used in this experiment with dimension of $50 \times 50 \times 70 \mathrm{~mm}$ (tangential $\times$ radial $\times$ longitudinal). The moisture content (MC) of the samples prior to treatment ranged from 15 to $18 \%$. The samples were conditioned at $65 \%$ relative humidity $(\mathrm{RH})$ and $20^{\circ} \mathrm{C}$ for 6 weeks to attain equilibrium moisture content (EMC) before the treatment. Silicone oil heat treated $P$. massoniana samples were divided into 9 treatments, plus one set as untreated.

\section{Silicone oil heat treatment}

Treatment of the wood was carried out in oil bath containing commercial grade silicone oil with programmable controller. Silicone oil served as a medium of heat transfer. The samples were pre-heated in a micro-wave oven for 5 minutes to ease heat transfer within the wood. After pre-treatment, samples were transferred and immersed in a pre-heated oil bath at 150,180 or $210^{\circ} \mathrm{C}$ for 2,4 or 8 hours at each defined temperature. Finally, the samples were conditioned in a climate chamber at $65 \pm 5 \% \mathrm{RH}$ and $20 \pm 2{ }^{\circ} \mathrm{C}$ until the weight change in the samples was less than $0,1 \%$.

\section{Chemical properties}

Samples of untreated and silicone oil heat treated P. massoniana were sliced into chips and then milled with Wiley mill to sawdust. The extractive content were determined according to ASTM D-1107-96 (2007). The lignin contents were determined according to Okon et al. (2017) and ash content according to ASTM D-1102-96 (2007). The polysaccharide content was calculated by the addition of the mass of cellulose to the mass of hemicellulose (cellulose + hemicellulose). Two replicates were determined from each sample with average taken and data were presented as percentage of the oven-dry weight.

\section{Fourier transformed infrared (FTIR) analysis}

Infrared spectra of reference and silicone oil heat treated P. massoniana samples were recorded at room temperature with a Vertex 70 spectrometer (both Bruker Optik GmbH, Germany). Each sample powder was mixed uniformly with potassium bromide $(\mathrm{KBr})$ at the ratio of 1:100 $(\mathrm{w} / \mathrm{w})$, milled into fine powder and then pressed to form a thin pellet. Spectra acquisition was recorded in transmission mode in the range of 4000 to $500 \mathrm{~cm}^{-1}$ with a spectra resolution of $9 \mathrm{~cm}^{-1}$, with 15 scans taken for both background and samples spectra. Baseline - correction and intensity normalization of the spectra were carried out automatically.

\section{Thermogravimetric analysis (TGA)}

The thermogravimetric analysis was performed under nitrogen atmosphere with thermal analyser (NETZSCH STA 449F3, Germany) in order to study the degradation of the reference and silicone oil heat treated samples. Approximately $8,16 \mathrm{mg}$ samples of each treatment were put in DSC/TG pan. The samples were heated at $10^{\circ} \mathrm{C} \mathrm{min}-1$, temperature $25^{\circ} \mathrm{C}-600^{\circ} \mathrm{C}$ and a flow rate of $30 \mathrm{ml} \mathrm{min}^{-1}$. The samples were then cooled at $-10^{\circ} \mathrm{Cmin}^{-1}$ until they returned to room temperature. The curve of TGA data was plotted using Origin 8,0 .

\section{X-ray diffraction (XRD) Characterization}

The XRD of the reference and silicone oil heat treated samples were analysed with an X-ray diffractometer (Japan, Rigaku Ultima IV) by $\mathrm{Cu}-\mathrm{K} \alpha$ radiation $\left(\lambda=1,5418 \AA\right.$ ) with $2 \theta$ range of $5-60^{\circ}$, voltage $40 \mathrm{kV}$, electric current $40 \mathrm{~mA}$, water flow $4,6 \mathrm{~L} \mathrm{~min}^{-1}$ and scanning of $0,1^{\circ} \mathrm{min}^{-1}$. The crystallinity index (CI) of both the untreated and silicone oil heat treated samples was calculated according to the patent developed by Segal 
et al. (1959) with Equation 1.

$$
\mathrm{CI}(\%)=\frac{\mathrm{I}_{002}-\mathrm{I}_{\mathrm{am}}}{\mathrm{I}_{002}} \times 100
$$

Where $\mathrm{I}_{002}=$ diffraction intensity of crystalline peak at $20,08^{\circ}-25,08^{\circ} 2 \theta, \mathrm{I}_{\mathrm{am}}=$ the intensity of the amorphous peak at $15^{\circ}-18^{\circ} 2 \theta$.

\section{Contact angle measurement}

The measurement of the contact angle (wettability) of the untreated and silicone oil heat treated samples was performed with a Drop Shape Analyser DSA100 (Krüss GmbH, Hamburg, Germany). 10 samples were used for each treatment, 2 drops per samples were captured and 20 measurements of contact angles were obtained and the mean value was reported. Deionized water $(5 \mu \mathrm{L})$ was dropped at the tangential surface of the samples and the acquisition of the contact angle was taken automatically for every 5 seconds with the general conic section method (tangential method 1). All samples were maintained at standard room temperature $(25 \pm$ $2^{\circ}$ ) and $\mathrm{RH} 20 \pm 2^{\circ} \mathrm{C}$.

\section{Statistical analysis}

The chemical composition data was analysed with analysis of variance (ANOVA). Tukey Honest Significant Difference (HSD) multiple comparisons of means were used to separate the means at a significance level of $\mathrm{P}<0,05$. All the analyses were performed with $\mathrm{R}$ version 3.1.1 statistical software (Team 2014).

\section{RESULTS AND DISCUSSION}

\section{Chemical properties of silicone heat treated wood}

The results of this study indicate that the chemical properties of the P. massoniana wood were affected after silicone oil heat treatment and the polysaccharide content of the treated wood samples decreased with increase of treatment temperature. The polysaccharides content was $75 \%$ in the untreated sample. It ranged from $64,48 \%$ when treated at $150^{\circ} \mathrm{C}$ for $2 \mathrm{~h}$ to $43,30 \%$ when treated at $210^{\circ} \mathrm{C}$ for $8 \mathrm{~h}$ in the silicone oil heat treated samples, was significantly different from the untreated $(\mathrm{P}<0,0001 \mathrm{~F}=155,71)$ (Table 1$)$. The decrease in the polysaccharide content occurred as a result of the thermal degradation of the wood constituent particularly hemicelluloses. According to Wentzel et al. (2019) degradation of hemicellulose is higher in a closed system modifications than in an open system modifications, due to the high concentrations of acids that build up as a result of pressure. Hemicelluloses degrade with ease when wood is subjected to heating even at low temperatures because of its relative low thermal stability. The lower thermal stability of hemicelluloses in relationship with cellulose which is linear homopolysaccharide is usually explained by its lack of crystallinity (Yildiz and Gümüşkaya 2007, Korošec et al. 2009). According to Weiland et al. (1998) the heat-treatment of wood in the temperature range between 200 and $260^{\circ} \mathrm{C}$ causes strong hemicellulose degradation with significant release of acetic acid. The decrease in polysaccharides content depends largely on the treatment temperatures and wood species. High heat treatment temperature gives rise to acid hydrolysis of polysaccharides. Alen and Kotilainen (2000) reported higher decrease in polysaccharide content of heat treated Betula pendula compared to Pinus slyvestris wood after treatment, resulting in the formation of furans such as furfural and hydoxymethyl furfural (Rowel et al. 2009). Our results are in line with previous studies on the changes in the polysaccharide content of thermally modified wood, treated between $140-260^{\circ} \mathrm{C}$ temperature range (Yildiz et al. 2006, Bourgois et al. 1989).

Lignin content of the wood samples varied significantly between treatments $(\mathrm{P}<0,0001 \mathrm{~F}=55,412)$ with untreated having the lowest mean lignin of $25,10 \%$ and the silicone oil heat treated samples at $210^{\circ} \mathrm{C}$ for 8 $\mathrm{h}$ having the highest mean lignin value of $41,38 \%$. (Table 1). This result confirms the effectiveness of the treatment as relative significant increase in lignin occurred when $P$. massoniana wood was treated at $210^{\circ} \mathrm{C}$ for $8 \mathrm{~h}$. Lignin content of the wood increased with the increase of treatment temperature and time. The increase 
in lignin content has been observed in Eucalyptus grandis (Lengowski et al. 2018). This may be explained by the fact that the highly structural branched phenylpropanoid units, which make up lignin, impart rigidity and resistance to wood and other lignocellulose materials. This makes lignin relatively thermally most stable component of wood compared to other wood constituents. Though, degradation starts at the beginning of heat treatment process, but at a slower rate against polysaccharides (Windeisen et al. 2007, Esteves et al. 2008a). Brito (2008) asserted that the relative lignin content increased with elevated temperature and longer treatment time result to the consequent decrease in polysaccharide. The observed increase in relative lignin content after silicone oil heat treatment of the wood is most likely due to the condensation of polysaccharide by-products retained in the lignin fraction during lignin determination (Yildiz et al. 2006, Mitchell et al. 1953, GonzálezPeña et al. 2009).

Lower mean extractive content was obtained in the untreated samples $(2,63 \%)$, compared to the silicone oil heat treated samples with higher extractives which ranged between $5,04 \%$ at $150^{\circ} \mathrm{C}$ for $2 \mathrm{~h}$ to $13,99 \%$ at $210^{\circ} \mathrm{C}$ for $8 \mathrm{~h}$. There was significant difference between the treated samples in comparison with the untreated $(\mathrm{P}<0,0001 \mathrm{~F}=22,23)$ (Table 1). The greatest effect of the treatment on the wood occurred at $210^{\circ} \mathrm{C}$ for 8 h. Similar results were reported by Severo et al. (2016) on the effect of thermal treatment on the chemical composition of Hevea brasiliensis wood. They asserted that the increase in extractive content during thermal treatment was due to the degradation of holocellulose. Okon et al. (2017) also reported increase in extractive content with increase of treatment temperature and the impregnation of the silicone oil during heat treatment and solubilisation of water extractives can lead to increase in the content of extractives (Esteves et al. 2011, Tong and Zhang 2016). Extractives are non-structural components in wood constituents that can change at high heat treatment temperature, some evaporates easily during thermal treatment, particularly the most volatile compounds (Esteves and Pereira 2008, Yildiz and Gümüsskaya 2007) and new compounds may be formed at the same time (Esteves et al. 2008a, Cademartori et al. 2013). As a result of this, the dynamic wettability of the treated wood may be improved. As with ash content, higher mean value was reported in the untreated samples compared to the silicone oil heat treated samples, with reduced mean of $8,48 \%$ at $150^{\circ} \mathrm{C}$ for $2 \mathrm{~h}$ and $1,62 \%$ at $210^{\circ} \mathrm{C}$ for $8 \mathrm{~h}$. There was significant variation in the ash content of treated samples $(\mathrm{P}<0,0001 \mathrm{~F}=79,45)$ compared to the untreated (Table 1). This result is consistent with literature results indicating decrease in ash content, no possible reason was stated to be cause of the decrease (Da Silva et al. 2015, Herrera et al. 2014). However, many studies have been conducted regarding the chemical composition of wood ash, with widely varying results. Some reported calcium carbonate $\left(\mathrm{CaCO}_{3}\right)$ as the major constituent, others reported the present of calcium oxide (CaO) instead (Naik et al. 2001, Etiegni and Campbell 1991).

Table 1: Mean changes in chemical composition of Pinus massoniana wood as a result of silicone oil heat treatment at different temperatures.

\begin{tabular}{|c|c|c|c|c|c|}
\hline $\begin{array}{l}\text { Silicone Oil Heat } \\
\text { Treatment }\left({ }^{\circ} \mathrm{C}\right)\end{array}$ & $\begin{array}{l}\text { Time } \\
\text { (h) }\end{array}$ & $\begin{array}{c}\text { Polysaccharides } \\
(\%)\end{array}$ & $\begin{array}{c}\text { Lignin } \\
(\%)\end{array}$ & $\begin{array}{c}\text { Extractives } \\
(\%)\end{array}$ & $\begin{array}{l}\text { Ash } \\
(\%)\end{array}$ \\
\hline \multirow{2}{*}{ Untreated } & & $75,16 \pm 0,05^{\mathbf{h}}$ & $25,10 \pm 0,06^{a}$ & $2,63 \pm 1,87^{a}$ & $13,11 \pm 0,32^{\mathbf{g}}$ \\
\hline & 2 & $64,48 \pm 0,36^{\mathbf{g}}$ & $27,62 \pm 0,07^{\mathbf{a b}}$ & $5,04 \pm 0,16^{\mathbf{a b}}$ & $8,48 \pm 0,31^{\mathbf{f}}$ \\
\hline \multirow[t]{3}{*}{150} & 4 & $63,66 \pm 1,21^{\mathrm{fg}}$ & $28,02 \pm 1,03^{\mathbf{a b}}$ & $6,49 \pm 1,43^{\text {ac }}$ & $7,01 \pm 0,03^{\text {ef }}$ \\
\hline & 8 & $62,82 \pm 2,55^{\mathrm{fg}}$ & $29,70 \pm 0,63^{\mathbf{b c}}$ & $8,56 \pm 1,18^{\text {bcd }}$ & $7,01 \pm 1,09^{\text {df }}$ \\
\hline & 2 & $60,28 \pm 0,14^{\text {ef }}$ & $30,40 \pm 0,39^{\mathbf{b c}}$ & $9,43 \pm 0,71^{\text {ce }}$ & $6,50 \pm 0,12^{\text {df }}$ \\
\hline \multirow[t]{3}{*}{180} & 4 & $58,00 \pm 0,82^{\mathrm{de}}$ & $32,34 \pm 0,55^{\text {cd }}$ & $9,88 \pm 0,14^{\text {cf }}$ & $5,61 \pm 0,25^{\text {cde }}$ \\
\hline & 8 & $55,72 \pm 0,57^{\mathrm{cd}}$ & $34,47 \pm 2,23^{\text {de }}$ & $10,70 \pm 0,18^{\text {cf }}$ & $5,26 \pm 0,03^{\text {cd }}$ \\
\hline & 2 & $52,03 \pm 0,93^{\mathbf{b c}}$ & $36,17 \pm 1,00^{\text {de }}$ & $11,35 \pm 1,65^{\text {def }}$ & $3,90 \pm 0,50{ }^{\mathbf{b c}}$ \\
\hline \multirow[t]{2}{*}{210} & 4 & $49,96 \pm 0,48^{\mathbf{b}}$ & $38,11 \pm 1,27^{\text {ef }}$ & $13,57 \pm 0,98^{\text {ef }}$ & $3,11 \pm 0,90^{\mathbf{a b}}$ \\
\hline & 8 & $43,30 \pm 0,07^{\mathbf{a}}$ & $41,38 \pm 0,20^{\mathrm{f}}$ & $13,99 \pm 0,73^{\mathbf{f}}$ & $1,62 \pm 0,08^{a}$ \\
\hline
\end{tabular}

The Mean values in percentage \pm standard deviation was determined in each treatment. Superscript within each column, followed by different letters of the alphabets are significantly different from the reference at

$$
\mathrm{p}<0,05 \text {. }
$$

\section{FTIR analysis}

The FTIR spectra of the untreated and silicone oil heat treated samples were presented at $4000-500 \mathrm{~cm}^{-1}$, the differences in the spectra of the untreated and treated samples at different treatment time were evaluated to understand the structural changes that occur within the polymeric structure of the wood during silicone oil heat 
treatment. The spectra of silicone oil heat treated P. massoniana were relatively modified in relationship to the untreated wood, which indicated obvious changes in chemical composition of the wood due to modification (Figure 1). FTIR spectra of the silicone oil heat treated samples represented characteristic peaks at $3420 \mathrm{~cm}^{-1}$ (O-H stretching) which attest to the loss of hydroxyl groups as a result of polymer dehydration after silicone oil heat treatment (González-Peña et al. 2009). The absorption peak of the treated wood at $2970 \mathrm{~cm}^{-1}$ increased, which was attributable to the stretching vibration of $\mathrm{C}-\mathrm{H}$ in methyl and methylene. This result indicated that extractive content shifted, while polysaccharide in the hemicelluloses were hydrolysed (Wang et al. 2017 ). The FTIR spectra from 1740-500 $\mathrm{cm}^{-1}$ are considered as the finger print of wood (Pandey 1999). The absorbance peak at $1740 \mathrm{~cm}^{-1}$ generally increased, representing $\mathrm{C}=\mathrm{O}$ stretching of the acetyl groups of galactoglucomannan, carboxyl and aldehydes and aromatic/conjugated aldehydes and esters in lignin (Gérardin et al. 2007, Tjeerdsma and Militz 2005). Okon et al. (2017) asserted that the absorption peak at $1510 \mathrm{~cm}^{-1}$ represented a characteristic band for $\mathrm{C}=\mathrm{C}$ stretching assigned to aromatic skeletal vibrations, attributed to the change in the lignin content of silicone oil heat treated P. massoniana wood. Compared to the untreated wood, the intensity of treated P. massoniana increased at this band, and this is similar to the results reported in previous studies (Akgül et al. 2007, Kotilainen et al. 2000). The increase in the intensity of the silicone oil heat treated wood samples leads to increase in lignin content and corresponding degradation of polysaccharide content in the wood samples. The peaks at $1270 \mathrm{~cm}^{-1}$ correspond to C-O-C stretching asymmetric band in cellulose and hemicellulose. The increasing band intensities after silicone heat treatment corresponds to $\mathrm{CH}_{3}$-Si stretching in silicone oil. This indicates the contributions of syringyl and quaiayl lignin condensed unit and characteristic stretching vibrations of mostly carbohydrate chemical groups (e.g ester). The band at $920 \mathrm{~cm}^{-1}$ was intense in the silicone oil heat treated than in the untreated wood. This band is associated with C-H anti-symmetric out-of-phase distortion in cellulose and hemicelluloses (Cotana et al. 2014). Also the band was assigned to the Si-C, Si-O and Si-O-CH $\mathrm{CH}_{3}$ groups (Selamoglu et al. 1989), signifying that silicone oil was absorbed by the wood during treatment. The FTIR spectroscopy has shown that silicone oil heat treatment has impact on the wood chemical structure and there was changed in the chemical composition between silicone oil heat treated $P$. massoniana and the untreated. FTIR spectroscopy results showed that polysaccharide content were decreased, while lignin contents were increased after silicone oil heat treatment.

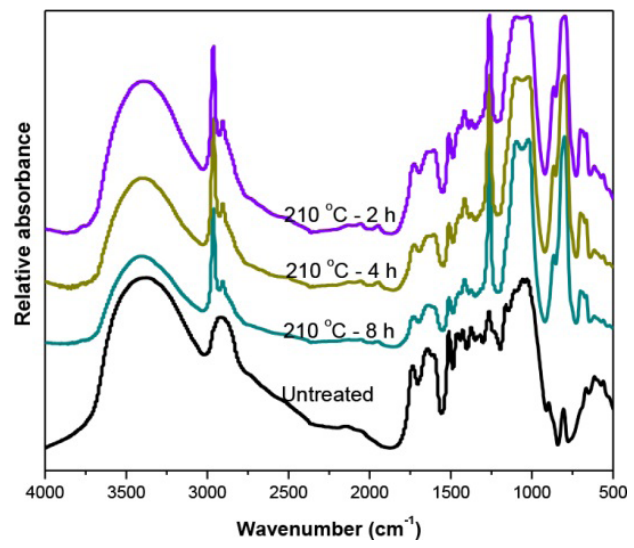

Figure 1: Infrared spectra of untreated and silicone oil heat treated Pinus massoniana wood. FITR spectra of the reference samples and silicone oil treated samples at $210^{\circ} \mathrm{C}$ for $2 \mathrm{~h}, 210^{\circ} \mathrm{C}$ for $4 \mathrm{~h}$, and $210^{\circ} \mathrm{C}$ for $8 \mathrm{~h}$. Wavenumber range from $4000-500 \mathrm{~cm}^{-1}$.

\section{Thermal properties}

Thermal stability and decomposition of untreated and silicone oil heat treated P. massoniana wood are presented in thermogravimetric (TG), and its derivative thermogravimetric (DTG) curves (Figure 2a and Figure $2 b$ ). Different stages of decomposition were observed for both the untreated and treated wood samples (Figure 2a). The initial mass loss occurred from 25 to $150^{\circ} \mathrm{C}$ and is attributed to moisture evaporation in the wood matrix, i.e devolatilization process has started, causing mass loss in the wood. The second mass loss region was from $280-380^{\circ} \mathrm{C}$, the ratio of weight loss for the untreated samples was 5,26 \% and 4,60\% for the silicone oil heat treated samples at $210^{\circ} \mathrm{C}$ for $8 \mathrm{~h}$. At this stage, hemicelluloses and cellulose were sharply and continuously degrading at this temperature range. Missio et al. (2015) had earlier reported the decomposition of cellulose 
in this temperature range, but Yang et al. (2007) asserted that it was difficult to separate each thermal event as both hemicellulose and cellulose decompose within the same temperature. Almost all the structural components of $P$. massoniana undergo thermal decomposition, suggesting that crystalline properties of cellulose may have been affected. The third mass loss region was from 380 to $600^{\circ} \mathrm{C}$, with weight loss of $69,02 \%$ in the untreated wood samples and $64,20 \%$ for the treated samples at $210^{\circ} \mathrm{C}$ for $8 \mathrm{~h}$. The gradual mass loss observed from the curves is due to the decomposition of lignin. Lignin is the most thermally stable chemical component of wood (Esteves et al. 2008b, Sandermann and Augustin 1964), whose decomposition begins at relatively low treatment temperature and lasts up to $600^{\circ} \mathrm{C}$. Hosoya et al. (2007) also reported that the main degradation of hemicelluloses and cellulose occurred at $220-350^{\circ} \mathrm{C}$ and $315-400^{\circ} \mathrm{C}$ and that of lignin covered the temperature range between $150-900^{\circ} \mathrm{C}$. As is evident in the TGA results, the thermal stability of the silicone oil heat treated samples increased with regards to the untreated samples, mainly due to the aromatic condensation of lignin unit present in the treated wood.

According to Bahadur and Sastry (2005), DTG curve is a plot of the rate at which mass changes within a time range with regards to temperature and is used to evaluate the point at which mass loss is most visible. As shown in the DTG curves in Figure 2b, the untreated wood has significantly higher reactivity, compared to silicone oil heat treated wood, which is due to the decomposition of hemicellulose present in higher quantity in the untreated wood. On the other hand, relatively high rate of mass loss occurred at a slightly higher temperature of $359^{\circ} \mathrm{C}$ for silicone oil heat treated P. massoniana wood at 210 for $8 \mathrm{~h}$ compared to the untreated (Figure $2 \mathrm{~b}$ ). This can be explained by the fact that silicone oil heat treatment significantly modified the chemical components of the wood and the heat treated $P$. massoniana wood showed more chemically homogeneous structure, composed mainly of cellulose and lignin (Okon et al. 2018a). Immense mass loss was obtained between the temperatures of $240^{\circ} \mathrm{C}$ to $380^{\circ} \mathrm{C}$, as indicated in the TG peak. Previous studies explained that, the peak came as a result of the overlap caused by the decomposition of hemicellulose and celluloses (Acquah et al. 2017). At temperature of $400^{\circ} \mathrm{C}-600^{\circ} \mathrm{C}$, greater mass loss was obtained, which suggest the degradation of lignin. This confirms the results of Acquah et al. (2017) that lignin decomposed over a wider temperature range compared to polysaccharide content. This presents the horizontal tail in the DTG of lignocellulosic materials (Figure 2b).
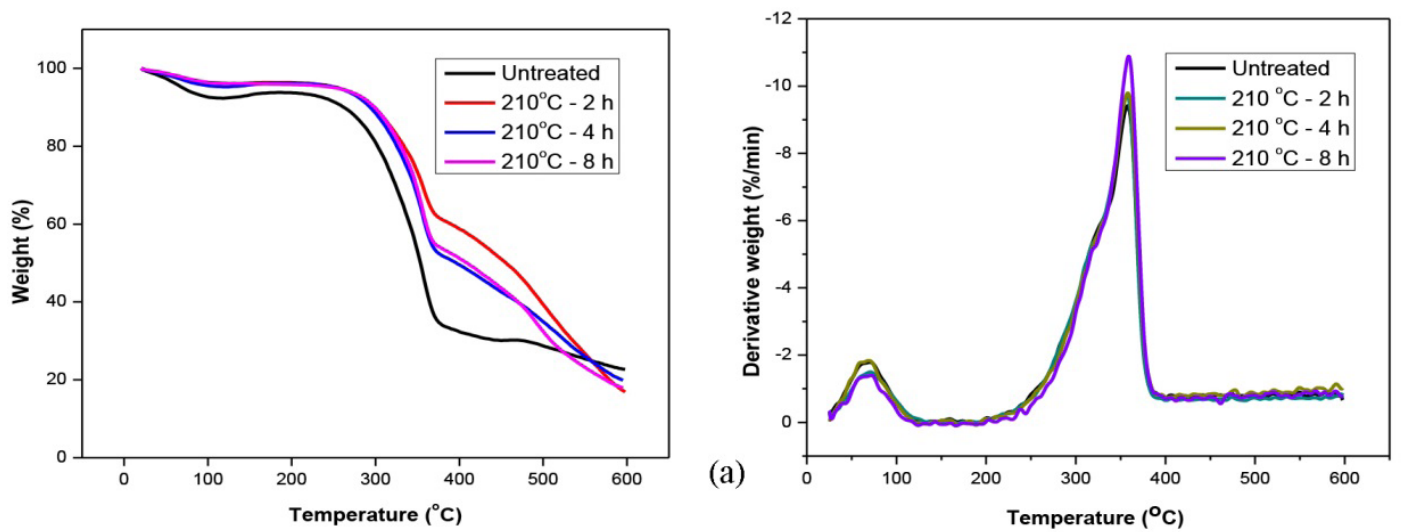

Figure 2: Thermogravimetric analysis (TGA) of untreated and silicone oil heat treated Pinus massoniana. (a) Thermogravimetric (TG) and (b) derivative thermogravimetric (DTG).

\section{X-ray diffraction}

Figure 3 shows XRD patterns of untreated and silicone oil heated treated P. massoniana wood. Distinct changes were observed in the XRD of the wood samples with typical cellulose I spectra. The silicone oil heat treated wood at $210^{\circ} \mathrm{C}$ for different exposure time, indicate broad bands in the range $2 \theta=5-18,70^{\circ}$. This range mostly emanated from more disordered structure (O'Connor et al. 1958). The diffraction peaks shifted to lower angles with the increase of treatment time because of the thermal expansion behaviour of the wood crystals. The amorphous cellulose in the untreated wood was significantly high compared to the treated wood samples. Crystallographic (110), (200) and (004) planes, which appeared at $2 \theta=12,10 ; 22,60$ and $34,80^{\circ}$, respectively were clear on the spectra and crystallographic planes were labelled according to the cellulose I structure described by Sugiyama et al. (1991). The peak intensities increased during treatment for all three peaks and two strong diffraction peaks were noticed in the heat treated wood at $2 \theta=12,10$ and $22,60^{\circ}$ which 
can be referred to be the crystalline planes of the cellulose of wood. The sharp diffraction peaks obtained after oil heat treatment of the wood samples at $210^{\circ} \mathrm{C}$ for $2 \mathrm{~h}, 4 \mathrm{~h}$, and $8 \mathrm{~h}$ respectively, revealed higher crystallinity in comparison with the untreated. Treatment of $P$. massoniana with silicone oil changes the Crystallinity index (CI) as well as crystal structure of the wood. The CI of untreated and silicone oil heat treated samples obtained from XRD curve are shown in Table 2. The CI of all the heat treated wood increased relatively with increase of treatment time up to $40,85 \%$, compared to the untreated. It is interesting to note that the significant changes in relative crystallinity are most likely due to polysaccharide depolymerization at high temperature. Esteves $e t$ al. (2008b) reported in their studies that after heat treatment, the fraction of crystalline cellulose increased due to the decomposition of the polysaccharides content. The increase in the peaks of wood after heat-treatment indicated that the crystalline structure in the wood was not damaged by the treatment. Thus, silicone oil heat treatment method used in this study modified the wood properties of $P$. massoniana wood.

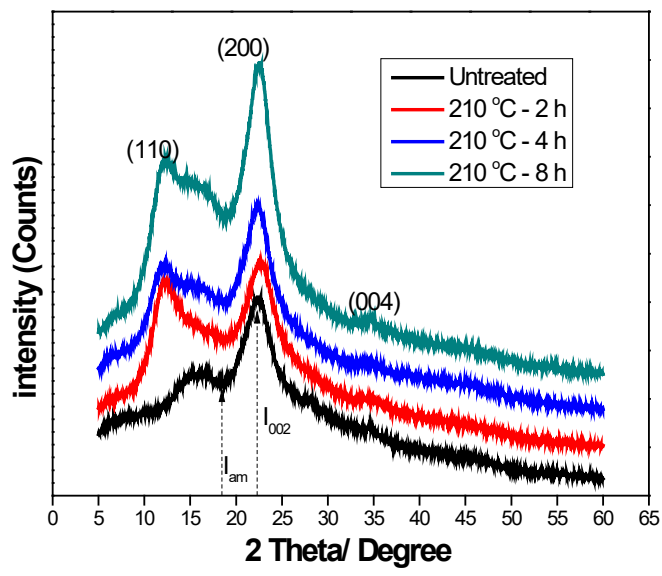

Figure 3: Comparison of $\mathrm{X}$ - Ray diffractogram of Pinus massoniana wood samples, untreated and silicone oil heat treated at $210^{\circ} \mathrm{C}$ for $2 \mathrm{~h}, 210^{\circ} \mathrm{C}$ for $4 \mathrm{~h}, 210^{\circ} \mathrm{C}$ for $8 \mathrm{~h}$. XRD spectra suggest better crystallinity after silicone oil heat treatment at high temperature.

Table 2: Crystallization index of silicone oil heat treated Pinus massoniana wood samples.

\begin{tabular}{|c|c|c|}
\hline Silicone oil heat treatment $\left.{ }^{\mathbf{0}} \mathbf{C}\right)$ & Time (h) & Crystallinity index (\%) \\
\hline Untreated & & $35,26 \pm 0,02$ \\
\hline 210 & 2 & $40,13 \pm 0,01$ \\
\hline 210 & 4 & $40,52 \pm 0,01$ \\
\hline 210 & 8 & $40,85 \pm 0,04$ \\
\hline
\end{tabular}

Mean \pm standard deviation.

\section{Wettability}

The contact angle of the untreated and silicone oil heat treated P. massoniana wood samples (Figure 4 and Figure 5) clearly indicated that the wood was resistant to liquid water absorption. Contact angle was measured to assess the water repellence of the modified wood and the resultant wettability values were higher in all the silicone oil heat treated wood. As shown in Figure 5a, the water droplet instantaneously spreads on the surface of the untreated wood at contact angle of $\sim 36^{\circ}$ as a result of the hydrophilic nature of the wood. However, after heat-treatment with silicone oil, the wood exhibited improved water resistance, therefore becoming hydrophobic in nature with contact angles of $\sim 93$ and $104^{\circ}$, when treated at $210^{\circ} \mathrm{C}$ for $2 \mathrm{~h}$ and $210^{\circ} \mathrm{C}$ for $4 \mathrm{~h}$ (Figure 5b and Figure 5c). Furthermore, silicone oil heat treatment of the wood at $210^{\circ} \mathrm{C}$ for longer time of $8 \mathrm{~h}$ resulted in a remarkable increase of contact angle of $\sim 135^{\circ}$ (Figure 5d), and deionized water droplet exhibited an almost perfect spherical shape on the wood surface, displaying super-hydrophobic properties on the treated 
wood. The contact angles of water for all silicone oil heat treated $P$. massoniana wood were significantly higher compared to the untreated, which indicated that the silicone oil heat treatment method was effective, increasing the wood hydrophobicity (Figure 4). According to Kong et al. ( 2017) a super-hydrophobic wood surface of excellent water resistance properties is expected to minimize wood and liquid-water interactions and thus may avoid water associated problems such as dimensional instability and fungal decay, due to the oxidation of hydroxyl groups of cellulose and hemicellulose constituents after thermal treatment (Paul et al. 1997). The lower wettability of the silicone heat treated samples is most probably caused by chemical changes in the wood structure, such as auto-condensation of lignin, hemicelluloses decomposition and surface inactivation (Kim et al. 2014).

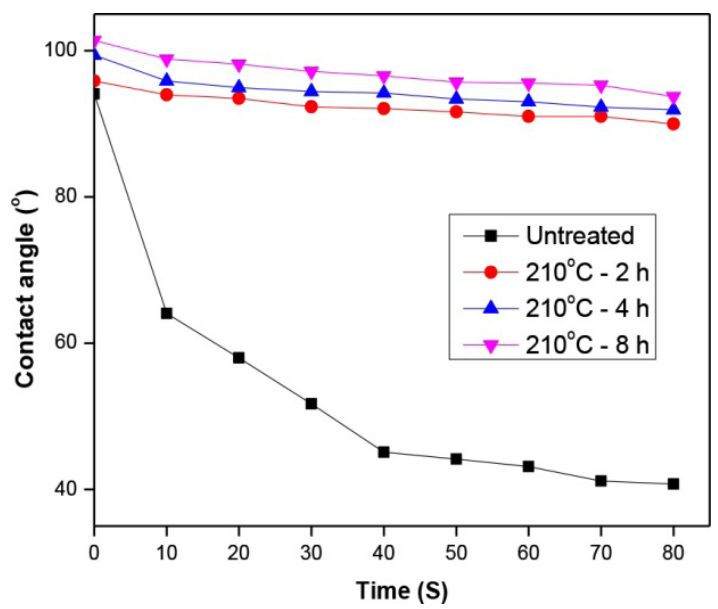

Figure 4: Contact angle of untreated and silicone oil heat treated Pinus massoniana wood samples at $210{ }^{\circ} \mathrm{C}$ for $2 \mathrm{~h}, 210^{\circ} \mathrm{C}$ for $4 \mathrm{~h}, 210^{\circ} \mathrm{C}$ for $8 \mathrm{~h}$.
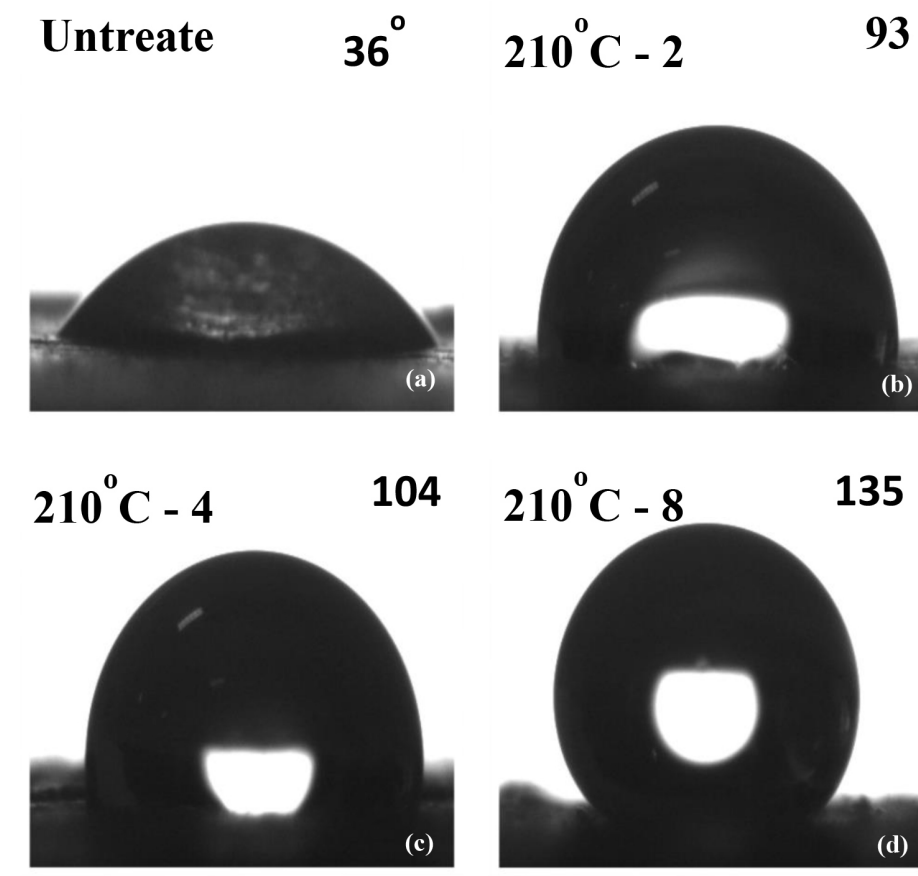

Figure 5: Images of $5 \mu \mathrm{L}$ water droplets on $P$. massoniana wood surface. (a) untreated wood, (b) silicone oil heat treated wood at $210^{\circ} \mathrm{C}$ for $2 \mathrm{~h}$, (c) silicone oil heat treated wood at $210^{\circ} \mathrm{C}$ for $4 \mathrm{~h}$, (d) silicone oil heat treated wood at $210^{\circ} \mathrm{C}$ for $8 \mathrm{~h}$. 


\section{CONCLUSIONS}

This work highlight the effects of silicone oil heat treatment on some chemical properties of $P$. massoniana wood. Silicone oil heat treatment changed chemical composition of the wood. Polysaccharide and ash contents of the wood decreased while lignin and extractives contents increased. FTIR spectra showed changes in the chemical structures of the wood and higher thermal stability as indicated by thermogravimetric analysis of silicone oil heat treated samples. The treatment increased the crystalline cellulose fraction of the wood and the crystalline structure was not damaged as the CI was increased. The wettability of the wood proved to be hydrophobic after silicone oil heat treatment. To further determine the effectiveness of the treatment, it is recommended that the mechanical properties of the wood be tested.

\section{ACKNOWLEDGEMENTS}

This study was funded Special Scientific Research Fund for Public Service Sectors of Forestry (Grant No. 201504603), Science and Technology Projects of Fujian Province (2014NZ003) and the National Natural Science Foundation of China (Grant No. 31370560, 31170520).

\section{REFERENCES}

Acquah, G.E.; Via, B.K.; Fasina, O.O.; Adhikari, S.; Billor, N.; Eckhardt, L.G. 2017. Chemometric modeling of thermogravimetric data for the compositional analysis of forest biomass. PloS One 12(3):e0172999.

Adebawo, F.; Naithani, V.; Sadeghifa, H.; Tilotta, D.; Lucia, L.; Jameel, H.; Ogunsanwo, O. 2016. Morphological and interfacial properties of chemically-modified tropical hardwood. RSC Advances 6(8): 6571-6576.

Akgül, M.; Gümüșkaya, E.; Korku, S. 2007. Crystalline structure of heat-treated Scots pine (Pinus sylvestris L.) and Uludağ fir (Abies nordmanniana (Stev.) subsp. bornmuelleriana (Mattf.) wood. Wood Science and Technology 41(3): 281.

Alen, R.; Kotilainen, R. 2000. Thermal behavior of Scots pine (Pinus sylvestris) and silver birch (Betula pendula) at $200-230^{\circ} \mathrm{C}$. Wood and Fiber Science 32(2):138-143.

Alma, M.; Hafizo, Lu, H.; Maldas, D. 1996. Dimensional stability of several wood species treated with vinyl monomers and polyethylene glycol-1000. International Journal of Polymeric Materials 32(1-4):93-99.

American Society for Testing and Materials. ASTM. 2007. Standard Test Methods for Ethanol- Toluene Solubility of Wood. ASTM D-1107-96. 2007.

American Society for Testing and Materials. ASTM. 2007. Standard Test Method for ash content in wood. ASTM D-1102-96. 2007.

Bahadur, P.; Sastry, N. 2005. Principles of polymer science. Alpha Science Int'l Ltd.

Bazyar, B. 2012. Decay resistance and physical properties of heat treated Aspen wood. BioResources 7(1):696-705.

Behr, G.; Bollmus, S.; Gellerich, A.; Militz, H. 2018. Improvement of mechanical properties of thermally modified hardwood through melamine treatment. Wood Material Science \& Engineering 13(5):262-270.

Bhuiyan, T.R.; Hirai, N. 2005. Study of crystalline behavior of heat-treated wood cellulose during treatments in water. Journal of Wood Science 51(1): 42-47.

Bourgois, J.; Bartholin, M.C.; Guyonnet, R. 1989. Thermal treatment of wood: analysis of the obtained product. Wood Science and Technology 23(4):303-310.

Brito, J.; Silva, F.; Leão, M.; Almeida, G. 2008. Chemical composition changes in Eucalyptus and Pinus woods submitted to heat treatment. BioResource Technology 99(18): 8545-8548.

Cademartori, P.H.G.; Dos Santos, P.S.; Serrano, L.; Labidi, J.; Gatto, D.A. 2013. Effect of thermal 
treatment on physicochemical properties of Gympie messmate wood. Industrial Crops and Products (45): 360-366.

Chen, X.; Dorvel, B.; Boopalachandran, P.; King, S. 2018. Dimensional stability and hardness improvement of southern yellow pine wood using divinylbenzene dioxide. European Journal of Wood and Wood Products 76(2):455-468.

Cotana, F.; Cavalaglio, G.; Nicolini, A.; Gelosia, M.; Coccia, V.; Petrozzi, A.; Brinchi, L. 2014. Lignin as co-product of second generation bioethanol production from ligno-cellulosic biomass. Energy Procedia 45: $52-60$.

Da Silva, M.R.; Brito, J.O.; Govone, J.S.; De Oliveira Machado, G.; Calil, C.; Christoforo, A.L.; Lahr, F.A.R. 2015. Chemical and mechanical properties changes in Corymbia citriodora wood submitted to heat treatment. International Journal of Materials Engineering 5(4): 98-104.

Dumanli, A.G.; Windle, A.H. 2012. Carbon fibres from cellulosic precursors: a review. Journal of Materials Science 47(10):4236-4250.

Engelund, E.T.; Thygesen, L.G.; Svensson, S.; Hill, C.A. 2013. A critical discussion of the physics of wood-water interactions. Wood Science and Technology 47(1):141-161.

Esteves, B.; Graca, J.; Pereira, H. 2008a. Extractive composition and summative chemical analysis of thermally treated eucalypt wood. Holzforschung 62(3): 344-351. 404.

Esteves, B.; Pereira, H. 2008. Wood modification by heat treatment: A review. BioResources 4(1):370-

Esteves, B.; Videira, R.; Pereira, H. 2011. Chemistry and ecotoxicity of heat-treated pine wood extractives. Wood Science and Technology 45(4): 661-676.

Esteves, B.; Marques, A.V.; Domingos, I.; Pereira, H. 2008b. Heat-induced colour changes of pine ( $P i$ nus pinaster) and eucalypt (Eucalyptus globulus) wood. Wood Science and Technology 42(5):369-384.

Etiegni, L.; Campbell, A.G. 1991. Physical and chemical characteristics of wood ash. Bioresource technology 37(2): 173-178.

Fuller, B.S.; Ellis, W.D.; Rowell, R.M. 1997. Hardened and fire retardant wood products. United States Patent US 5,609,915. 1997 Mar 11.

Gérardin, P.; Petrič, M.; Petrissan, M.; Lambert, J.; Ehrhrardt, J.J. 2007. Evolution of wood surface free energy after heat treatment. Polymer Degradation and Stability 92(4):653-657.

Goldstein, I.S. 1977. Wood technology: Chemical aspects. ACS Publications.

González-Peña, M.M.; Curling, S.F.; Hale, M.D. 2009. On the effect of heat on the chemical composition and dimensions of thermally-modified wood. Polymer Degradation and Stability 94(12):2184-2193.

Gunstone, F.D. 2011. Vegetable Oils in Food Technology: Composition, Properties and Uses. John Wiley \& Sons., Boca Raton.

Herrera, R.; Erdocia, X.; Llano-Ponte, R.; Labidi, J. 2014. Characterization of hydrothermally treated wood in relation to changes on its chemical composition and physical properties. Journal of Analytical and Applied Pyrolysis (107):256-266.

Hill, C.A. 2007. Wood modification: chemical, thermal and other processes. John Wiley \& Sons.

Hosoya, T.; Kawamoto, H.; Saka, S. 2007. Cellulose-hemicellulose and cellulose-lignin interactions in wood pyrolysis at gasification temperature. Journal of Analytical and Applied Pyrolysis 80(1):118-125.

Inari, G.N.; Petrissans, M.; Lambert, J.; Ehrhardt, J.; Gérardin, P. 2006. XPS characterization of wood chemical composition after heat-treatment. Surface and Interface Analysis 38(10):1336-1342.

Kim, J.Y.; Hwang, H.; Oh, S.; Kim, Y.S.; Kim, U.; Choi, J.W. 2014. Investigation of structural modification and thermal characteristics of lignin after heat treatment. International Journal of Biological Macromolecules 66:57-65. 
Kocaefe, D.; Poncsak, S.; Boluk, Y. 2008. Effect of thermal treatment on the chemical composition and mechanical properties of birch and aspen. BioResources 3(2):517-537.

Kong, L.; Tu, K.; Guan, H.; Wang, X. 2017. Growth of high-density ZnO nanorods on wood with enhanced photostability, flame retardancy and water repellency. Applied Surface Science 407: 479-484.

Korošec, R.C.; Lavrič, B.; Rep, G.; Pohleven, F.; Bukovec, P. 2009. Thermogravimetry as a possible tool for determining modification degree of thermally treated Norway spruce wood. Journal of Thermal Analysis and Calorimetry 98(1):189.

Kotilainen, R.A.; Toivanen, T.J.; Alén, R.J. 2000. FTIR monitoring of chemical changes in softwood during heating. Journal of Wood Chemistry and Technology 20(3):307-320.

Kučerová, V.; Kačíková, D.; Kačík, F. 2011. Alterations of extractives and cellulose macromolecular characteristics after thermal degradation of spruce wood. Acta Facultatis Xylologiae Zvolen 53(2):77-83.

Kučerová, V.; Lagaňa, R.; Výbohová, E.; Hýrošová, T. 2016. The Effect of Chemical Changes during Heat Treatment on the Color and Mechanical Properties of Fir Wood. BioResources 11(4):9079-9094.

Kučerová, V.; Výbohová, E. 2014. Changes of cellulose in hydrolysis of willow (Salix alba L.) wood. Chemicke Listy 108(11):1084-1089.

Lengowski, E.C.; Muñiz, G.I.B.D.; Klock, U.; Nisgoski, S. 2018. Potential use of NIR and visible spectroscopy to analyze chemical properties of thermally treated wood. Maderas-Cienc Tecnol 20(4):627-640.

Militz, H. 2002. Heat treatment technologies in Europe: Scientific background and technological stateof-art. ed. Proceedings of Conference on Enhancing the durability of lumber and engineered wood products. February, 11-13.

Militz, H.; Altgen, M. 2014. Processes and properties of thermally modified wood manufactured in Europe. Deterioration and protection of sustainable biomaterials. ACS Publication 269-285.

Missio, A.L.; Mattos, B.D.; De Cademartori, P.H.; Gatto, D.A. 2016. Effects of two-step freezing-heat treatments on japanese raisintree (Hovenia dulcis thunb.) wood properties. Journal of Wood Chemistry and Technology 36(1):16-26.

Missio, A.L.; Mattos, B.D.; De Cademartori, P.H.; Pertuzzatti, A.; Conte, B.; Gatto, D.A. 2015. Thermochemical and physical properties of two fast-growing eucalypt woods subjected to two-step freeze-heat treatments. Thermochimica Acta 615:15-22.

Mitchell, R.; Seborg, R.; Millett, M. 1953. Effect of heat on the properties and chemical composition of Douglas-fir wood and its major components. Journal of the Forest Products Research Society 3(4):38-42.

Naik, T.R.; Kraus, R.N.; Kumar, R. 2001. Wood Ash: A New Source of Pozzolanic Material. Report N. REP-435. UMW Center for By-Products Utilization.

O’connor, R.T.; Dupré, E.F.; Mitcham, D. 1958. Applications of infrared absorption spectroscopy to investigations of cotton and modified cottons Part I: physical and crystalline modifications and oxidation. Textile Research Journal 28(5):382-392.

Okon, K.E.; Lin, F.; Chen, Y.; Huang, B. 2017. Effect of silicone oil heat treatment on the chemical composition, cellulose crystalline structure and contact angle of Chinese parasol wood. Carbohydrate Polymers 164:179-185.

Okon, K.E.; Lin, F.; Chen, Y.; Huang, B. 2018a. Decay resistance and dimensional stability improvement of wood by low melting point alloy heat treatment. Journal of Forestry Research 29(6):1795-1805.

Okon, K.E.; Lin, F.; Lin, X.; Chen, C.; Chen, Y.; Huang, B. 2018b. Modification of Chinese fir (Cunninghamia lanceolata L.) wood by silicone oil heat treatment with micro-wave pretreatment. European Journal of Wood and Wood Products 76(1): 221-228.

Pandey, K. 1999. A study of chemical structure of soft and hardwood and wood polymers by FTIR spectroscopy. Journal of Applied Polymer Science 71(12):1969-1975.

Paul, A.; Joseph, K.; Thomas, S. 1997. Effect of surface treatments on the electrical properties of 
low-density polyethylene composites reinforced with short sisal fibers. Composites Science and Technology 57(1):67-79.

Rautkari, L.; Hill, C.A.; Curling, S.; Jalaludin, Z.; Ormondroyd, G. 2013. What is the role of the accessibility of wood hydroxyl groups in controlling moisture content? Journal of Materials Science 48(18):63526356.

Rowell, R.M.; Ibach, R.E.; Mcsweeny, J.; Nilsson, T. 2009. Understanding decay resistance, dimensional stability and strength changes in heat-treated and acetylated wood. Wood Material Sience and Engineering 4(1-2): 14-22.

Rowell, R. 2012. Chemical modification of wood to produce stable and durable composites. Cellulose Chemistry and Technology 46(7-8):443-448.

Sailer, M.; Rapp, A.O. 2001. Use of vegetable oils for wood protection. In: COST action E22 Environmental optimisation of wood protection. Conference in Einbek, Germany, 8-10 November 2001.

Sandermann, W.; Augustin, H. 1964. Chemical investigations on the thermal decomposition of wood. Part III: Chemical investigation on the course of decomposition. Holz als Roh-und Werkstoff 22(10): 377-378.

Seborg, R.; Tarkow, H.; Stamm, A. 1953. Effect of heat upon the dimensional stabilisation of wood. Journal Forest Products Research Society 3(3):59-67.

Segal, L.; Creely, J.; Martin, JR. A.; Conrad, C. 1959. An empirical method for estimating the degree of crystallinity of native cellulose using the X-ray diffractometer. Textile Research Journal 29(10):786-794.

Selamoglu, N.; Mucha, J.A.; Ibbotson, D.E.; Flamm, D.L. 1989. Silicon oxide deposition from tetraethoxysilane in a radio frequency downstream reactor: Mechanisms and step coverage. Journal of Vacuum Science \& Technology B: Microelectronics Processing and Phenomena 7(6):1345-1351.

Severo, E.T.D.; Calonego, F.W.; Sansigolo, C. 2012. Physical and chemical changes in juvenile and mature woods of Pinus elliottii var. elliottii by thermal modification. European Journal of Wood and Wood Products 70(5):741-747.

Severo, E.T.D.; Calonego, F.W.; Sansigolo, C.; Bond, B. 2016. Changes in the chemical composition and decay resistance of thermally-modified Hevea brasiliensis wood. PloS One 11(3): e0151353.

Sivonen, H.; Maunu, S.L.; Sundholm, F.; Jämsä, S.; Viitaniemi, P. 2002. Magnetic resonance studies of thermally modified wood. Holzforschung 56(6):648-654.

Stamm, A.J.; Tarkow, H. 1947. Dimensional stabilization of wood. Journal of Physical Chemistry 51:493-505.

Stamm, A. J. 1964. Wood and cellulose science. Ronald Press Co: New York, USA. p.549

Sugiyama, J.; Vuong, R.; Chanzy, H. 1991. Electron diffraction study on the two crystalline phases occurring in native cellulose from an algal cell wall. Macromolecules 24(14): 4168-4175.

Sun, R.; Sun, X.F. 2002. Structural and thermal characterization of acetylated rice, wheat, rye, and barley straws and poplar wood fibre. Industrial Crops and Products 16(3): 225-235.

Team, R.C. 2014. R: A language and environment for statistical computing. R Foundation for Statistical Computing: Vienna, Austria. 2013.

Tjeerdsma, B.; Boonstra, M.; Pizzi, A.; Tekely, P.; Militz, H. 1998. Characterisation of thermally modified wood: molecular reasons for wood performance improvement. European Journal of Wood and Wood Products 56(3):149-153.

Tjeerdsma, B.; Militz, H. 2005. Chemical changes in hydrothermal treated wood: FTIR analysis of combined hydrothermal and dry heat-treated wood. Holz als Roh-und Werkstoff 63(2):102-111.

Tong, L.; Zhang, W. 2016. Using Fourier transform near-infrared spectroscopy to predict the mechanical properties of thermally modified southern pine wood. Applied Spectroscopy 70(10):1676-1684.

Wang, X.; Zhang, Y.; Yu, Z.; QI, C. 2017. Properties of fast-growing poplar wood simultaneously treated 
with dye and flame retardant. European Journal of Wood and Wood Products 5(3): 325-333.

Weiland, J.; Guyonnet, R.; Gibert, R. 1998. Analysis of controlled wood burning by combination of thermogravimetric analysis, differential scanning calorimetry and Fourier transform infrared spectroscopy. Journal of Thermal Analysis and Calorimetry 51(1):265-274.

Welzbacher, C.R.; Rapp, A.O. 2004. Determination of the water sorption properties and preliminary results from field tests above ground of thermally modified material from industrial scale processes. In Proceedings IRG Annual Meeting, IRG/WP, 04-40279. The International Research Group on Wood Protection: Stockholm, Sweden.

Wentzel, M. Brischke, C. Militz, H. 2019. Dynamic and static mechanic properties of Eucalyptus nitens thermally modified in an open and closed reactor system. Maderas-Cienc Tecnol 21(2):141-152.

Wikberg, H.; Maunu, S.L. 2004. Characterisation of thermally modified hard-and softwoods by $13 \mathrm{C}$ CPMAS NMR. Carbohydrate Polymers 58(4):461-466.

Windeisen, E.; Strobel, C.; Wegener, G. 2007. Chemical changes during the production of thermo-treated beech wood. Wood Science and Technology 41(6): 523-536.

Yang, H.; Yan, R.; Chen, H.; Lee, D.H.; Zheng, C. 2007. Characteristics of hemicellulose, cellulose and lignin pyrolysis. Fuel 86(12):1781-1788.

Yildiz, S.; Gezer, E.D.; Yildiz, U.C. 2006. Mechanical and chemical behavior of spruce wood modified by heat. Building and Environment 41(12):1762-1766.

Yildiz, S.; Gümüșkaya, E. 2007. The effects of thermal modification on crystalline structure of cellulose in soft and hardwood. Building and Environment 42(1):62-67. 